\title{
The Correlation between Adversity Quotient with Geography Learning Outcomes of Students in Class $X$ at SMAN 1 Kasihan Yogyakarta
}

\author{
Yuliana Ria Ariska \\ Yogyakarta State University \\ Yogykarta, Indonesia \\ yuleariska93@gmail.com
}

\author{
Dyah Respati Suryo Sumunar \\ Yogyakarta State University \\ Yogyakarta, Indonesia \\ dyah_respati@uny.ac.id
}

\begin{abstract}
This study aims to determine the relationship between Adversity Quotient with the learning outcomes of geography of grade X SMAN 1 Kasihan Yogyakarta. This research is a quantitative research by using correlational type. The population in this research is all class $X$ in SMAN 1 Kasihan Yogyakarta. The selected samples are the students of class X IPS 1 and X IPS 2 consisting of 62 students using purposive sampling technique. In this research, there are two variables, Adversity Quotient and student geography learning outcomes. The data collection techniques used questionnaires to obtain the students' Adversity Quotient data and use the test techniques to obtain the students' geography learning data. Data analysis used pearson correlation formula. The results of data analysis show that there is a significant positive relationship between Adversity Quotient with the students' geography learning outcomes. Pearson correlation value shows that the value of $\mathbf{r} \mathrm{AQ}$ with geography learning result is $\mathbf{0 . 9 6 4}$. This figure shows strong correlation between AQ with student geography learning outcomes because $r>0.05$. This is reinforced by two asterisks $(* *)$ with siginifikansi 0.01 which indicates that the higher of the students' AQ level, then the higher of the students' geography learning outcomes.
\end{abstract}

Keywords - correlation; adversity quotient; learning outcomes; geography

\section{INTRODUCTION}

The advancement of global technology that developed in the current era gives a significant influence on the quality of education throughout the world including in Indonesia. Education is one of the most important aspects in creating qualified and productive human resources to be able to compete with other countries in an effort to advance their country.

The progress of education that continues to cause significant competitiveness in individuals to continue to learn and develop the potential that exists within, as well as motivate themselves to become individuals who excel and excel. One way to achieve these achievements can be pursued through formal education in schools. Formal education in schools helps in sharpening, developing and shaping intellectual intelligence, spiritual intelligence, student character and attitudes. Student achievement can be seen through student learning outcomes after the learning process implemented.

According to Anderson \& Krathwohl [1] explain the learning outcomes is a change in student behavior in the process of education or learning activities. The learning process is done on the basis of competency standards that have been established for the purpose of student success, so that the changes that exist in students will get the value or appreciation of the success of the changes obtained. As Savickiene [2] defines the learning outcome is a scheme one must be able to do at the end of its learning. Learning outcomes are a proof of the success of students in conducting learning activities in accordance with the criteria that are achieved and usually indicated by the value index.

The success of students by achieving high learning outcomes is a goal desired by all parties, such as the school, teachers, parents, and students themselves. In achieving this success, students often find barriers in every process. These barriers may come from individual (internal) or environmental (external) factors. As stated by Shang Pao Yeh \& Hsin Wei Fu [3] describes the dimensions that influence learning outcomes of student learning are (1) human factors, including teacher learning methods, and student learning motivation, (2) curriculum factors, including the number of students in classes, teaching materials, and interactive programs. (3) science and technology.

Schools have a standard of success in every lesson, such as the KBM set by the government. Students are required to be able to face the arrival and completion of tasks given by the teacher so that students are able to achieve the standard of success, so get maximum learning result. The ability of students to survive and transform barriers into an opportunity is an Adversity Quotient (AQ) intelligence. According Stoltz [4] ability and resilience of a person in the face of difficulties, failures, obstacles as well as change the difficulty and failure meanjadi opportunities to achieve goals or success called the Adversity Quotient (AQ). In an educational perspective, $A Q$ is the 
necessary force to continue to struggle when students face difficulties in achieving their performance. Basically, AQ can predict one's resilience and persistence and can be used to improve team effectiveness, relationships, family, community, culture, society, and organization [5].

AQ consists of four dimensions of CO2RE. Dimension C = control is or control. Dimension C asks: how much control do you feel about an event that causes difficulties ?. Dimension O2 = Origin and ownership is the origin and recognition. The $\mathrm{O} 2$ dimension implies two things: who or what is the origin of the difficulty? And to what extent do I acknowledge the consequences of the difficulty ?. The dimension of $\mathrm{R}=$ reach is range. This dimension $\mathrm{R}$ asks: to what extent will difficulties reach out to other parts of my life ?. Dimension $\mathrm{E}=$ endurance is endurance. This $\mathrm{E}$ dimension questions two related issues: how long will the difficulty last? And how long will the cause of the hardship take place? [6].

According to Stolzt [6], the level of $\mathrm{AQ}$ as a person is divided into three, namely climbers, campers and quitters. Climbers are those who always welcome the challenges presented to them. Climbers believes that things can and will happen, even if others will behave negatively and have decided that the path is impossible. Campers are those who are satisfied with self-sufficiency, and do not want to develop themselves. Campers when doing work that takes creativity and takes calculated risks, but they usually have a safe path. Quitters who tend to resist change and sabotage every opportunity of success, or avoid it and actively away from it. Quitters work just enough to live. They exhibit little ambition, low spirits and substandard quality.

Different abilities in each student give different effects of difficulty as well. There are students who feel they are capable of solving challenges and exams provided by teachers, but there are also students who feel desperate and give up when faced with the challenges given by teachers. Therefore, the level of AQ owned by each student is different based on the uniqueness of student interaction with the surrounding environment. The difficulty of the dilemma comes as the challenge gets worse, so more people can not face and overcome challenges. This problem is very concerning because it is associated with the attitude of surrender and despair for an individual in the face of a far worse challenge [7]. Researchers are interested to see whether there is a significant relationship between AQ students and the learning outcomes of geography students of class X IPS in SMAN 1 Kasihan, Yogyakarta.

\section{RESEARCH MEthodS}

This research is a research using quantitative approach with correlational research method. This study was conducted to determine the relationship between AQ students and students' geography learning outcomes. There are two variables in this research, AQ as free variable $(\mathrm{X})$ and geography learning result as dependent variable $(\mathrm{Y})$. The population in this study is all students of class X SMAN 1 Kasihan, Yogyakarta recorded in the academic year 2017/2018 as many as 255 students, with class details that is, class X MIPA 1, X MIPA 2, MIPA 3, MIPA 4, MIPA 5 MIPA 6 , IPS 1 and IPS 2. The number of samples used in this study amounted to 62 students consisting of 30 students class X IPS 1 and 32 students class X IPS 2. Sampling technique used is purposive sampling.

TABLE I. THE SAMPLE OF CLASS X IPS (SOCIAL)

\begin{tabular}{|c|c|c|}
\hline No & Class & Amount \\
\hline 1 & X IPS 1 & 30 students \\
\hline 2 & X IPS 2 & 32 students \\
\hline \multicolumn{2}{|c|}{ Sotal } & 62 students \\
\hline \multicolumn{2}{|c}{} \\
\end{tabular}

Data collection was done by using two ways, namely, using the instrument in the form of questionnaire to collect AQ data of the students, and using instrument test to collect data of students' geography learning result. Questionnaire used in this research is a test instrument AQ Stoltz [6] which then modified.

The AQ questionnaire instrument is a statement based on AQ dimensions, namely control, origin, \& ownership, reach and endurance. The questionnaire scale used to measure student AQ is the guttman scale. The choice of guttman scale used is yes and no, with the value of each statement having positive status yes = 1 , not $=0$, and the statement with negative status yes $=0$, not $=$ 1. The interval scale is changed to ordinal scale, into 3 categories climbers, campers, and quitters.

The instrument test used to obtain the students' geography learning results using multiple choice questions as much as 30 questions with the hydraulic material. Instrument test is selfmade by developing test questions from each expert and has been tested for validity.

In this research, the instrument test is the validity and reliability test to find out the feasibility of the questionnaire, and the parametric statistic preview test is tested normality and homogeneity. Then the data analysis is done using product moment correlation test and followed by linearity test and simple regression.

\section{RESULT}

The AQ questionnaire instrument tested consisted of 66 statement points. Based on the calculation of validity test by using Karl Pearson formula obtained 44 items with the value of $\mathrm{f}$-hit $>2.05$ which is valid and there are 22 items of questionnaire with $\mathrm{f}$-hit $<2.05$, so the item is considered void and not feasible for used. The calculation result reliability of questionnaire AQ instrument obtained reliability coefficient of 0.843 . Then, the test instrument tested consisted of 35 items. The validity test results obtained 30 valid question items with f-hit $>2.0518$, with reliability coefficient of 0.84 . 
Based on AQ data and geography learning result data of class X IPS students at SMAN 1 Kasihan, Yogyakarta which has been collected, then obtained calculation result for categorization of span on each responder by using SPSS are as follows:

TABLE II. AQ DATA AND STUDENTS’ GEOGRAPHY LEARNING OUTCOMES

\begin{tabular}{|c|c|c|c|c|c|}
\hline & N & Mean & Min & Max & Std. Dev \\
\hline AQ & 62 & 29.1 & 19 & 39 & 4.5 \\
\hline $\begin{array}{c}\text { Geography } \\
\text { learning outcomes } \\
\text { of the students }\end{array}$ & 62 & 7.7 & 5 & 9 & 1.0 \\
\hline
\end{tabular}

The table above shows that the highest AQ score of students is 39 and lowest 19 . The analysis results show the mean (M) of 29.1, the median (Me) of 29, and the standard deviation (SD) of 4.5. In the geography learning result data students get the mean value (M) of 7.7, median (Me) of 8 , and standard deviation (SD) of 1.0 .

Based on Table 1 above, the results of the range categories for AQ data and student geography learning results can be seen in the following table:

TABLE III. CATEGORIZATION OF STUDENTS’ AQ

\begin{tabular}{|l|l|l|l|l|l|}
\hline $\begin{array}{c}\text { Categor } \\
\mathbf{y}\end{array}$ & $\begin{array}{l}\text { Spreading } \\
\text { Classificati } \\
\text { on }\end{array}$ & $\begin{array}{c}\text { Inter } \\
\text { val }\end{array}$ & $\begin{array}{c}\text { Frequen } \\
\mathbf{c y}\end{array}$ & $\begin{array}{c}\text { Percentag } \\
\mathbf{e}\end{array}$ & $\begin{array}{c}\text { Categor } \\
\mathbf{y}\end{array}$ \\
\hline $\begin{array}{l}\text { Climber } \\
\mathrm{s}\end{array}$ & $\begin{array}{l}\mathrm{x}>(\mathrm{M}+1 \mathrm{SD} \\
)\end{array}$ & $>33.6$ & 12 & $19.35 \%$ & High \\
\hline Campers & $\begin{array}{l}(\mathrm{M}+\mathrm{SD}) \geq \mathrm{x} \\
\geq(\mathrm{M}-\mathrm{SD})\end{array}$ & $\begin{array}{l}33.6- \\
24.6\end{array}$ & 44 & $70.97 \%$ & Medium \\
\hline Quitters & $\mathrm{x}<(\mathrm{M}-\mathrm{SD})$ & $<24.6$ & 6 & $9.68 \%$ & Low \\
\hline Total & & & 62 & $100 \%$ & \\
\hline
\end{tabular}

Source: Processed Data of 2018

TABLE IV. CLASSIFICATION OF STUDENTS' GEOGRAPHY LEARNING OUTCOMES

\begin{tabular}{|l|l|l|l|l|l|}
\hline $\begin{array}{l}\text { Spreading } \\
\text { Classification }\end{array}$ & $\begin{array}{l}\text { Inter } \\
\text { val }\end{array}$ & $\begin{array}{l}\text { Mea } \\
\text { n }\end{array}$ & $\begin{array}{l}\text { Freque } \\
\text { ncy }\end{array}$ & $\begin{array}{l}\text { Percent } \\
\text { age }\end{array}$ & Category \\
\hline $\mathrm{x}>(\mathrm{M}+1 \mathrm{SD})$ & $>8.7$ & 8.5 & 6 & $9.67 \%$ & High \\
\hline $\begin{array}{l}(\mathrm{M}+\mathrm{SD}) \geq \mathrm{x} \geq(\mathrm{M}- \\
\mathrm{SD})\end{array}$ & $\begin{array}{l}8.7- \\
6.7\end{array}$ & 7.82 & 45 & $72.58 \%$ & Medium \\
\hline $\mathrm{x}<(\mathrm{M}-\mathrm{SD})$ & $<6.7$ & 6.25 & 11 & $17.75 \%$ & Low \\
\hline Total & & 62 & $100 \%$ & \\
\hline
\end{tabular}

See the percentage of AQ categorization of students in the high category of $19.35 \%$, medium category of $70.97 \%$ and low category of $9.67 \%$. Then on the learning outcomes, the percentage of categorization of the students' geography learning outcomes in the high category is $9.67 \%$, the medium category is $72.58 \%$ and the low value category is $17.75 \%$.

Data about AQ of students is obtained from AQ questionnaire of students with 62 respondents. The data are grouped into three categories namely climbers, campers and quitters. There are 12 students included in the category of climbers, there are 44 students included into the campers category and there are 6 students who fall into the quitters category.

The next data result is the result of normality test and homogeneity test of variance to AQ data of student and data of student geography learning result. Normality test for each sample was done using one sample kolmogorov smirnov test and to calculate homogeneity test using t-test anova sample.

TABLE V. THE RESULT OF NORMALITY TEST OF AQ DATA AND STUDENTS’ GEOGRAPHY LEARNING OUTCOMES

One-Sample Kolmogorov-Smirnov Test

\begin{tabular}{|c|c|c|c|}
\hline & & AQ & $\begin{array}{l}\text { GROGRAPHY } \\
\text { LEARNING } \\
\text { OUTCOMES }\end{array}$ \\
\hline \multicolumn{2}{|l|}{$\overline{\mathrm{N}}$} & 62 & 62 \\
\hline \multirow{3}{*}{ Normal Parameters } & Mean & 29.08 & 7.66 \\
\hline & $\begin{array}{c}\text { Std. } \\
\text { Deviation }\end{array}$ & 4.513 & 0.949 \\
\hline & Absolute & 0.107 & 0.146 \\
\hline \multirow{2}{*}{$\begin{array}{l}\text { Most Extreme } \\
\text { Differences }\end{array}$} & Positive & 0.107 & 0.114 \\
\hline & Negative & -0.086 & -0.146 \\
\hline \multicolumn{2}{|c|}{ Kolmogorov-Smirnov Z } & 0.846 & 1.153 \\
\hline \multicolumn{2}{|c|}{ Asymp. Sig. (2-tailed) } & 0.472 & 0.140 \\
\hline
\end{tabular}

Source: Processed Data of 2018

Based on the above table, obtained statistical test value of variance normality AQ of 0.472 and geography learning results of 0.140 with a significance level of 0.05 . The value of $L>L 0,05$ and not lies in the critical area so that $\mathrm{H} 0$ is accepted. This means that each group, the sample comes from a normally distributed population. 
TABLE VI. THE RESULT OF HOMOGENEITY TEST OF VARIANCE AQ WITH STUDENTS’ GEOGRAPHY LEARNING OUTCOMES

Test of Homogeneity of Variances

\section{GROGRAPHY LEARNING OUTCOMES}

\begin{tabular}{|c|c|c|c|}
\hline Levene Statistic & df1 & df2 & Sig. \\
\hline 13.356 & 13 & 42 & 0.000 \\
\hline
\end{tabular}

Source: Processed Data of 2018

Based on the calculation of the above table shows that the value of the significance of geographical learning results based on student AQ variable is $0.000>0.05$, meaning that variable data has the same variant which means the data is homogeneous.

TABLE VII. THE RESUlTS OF PEARSON CORRELATION TEST AQ WITH STUDENTS’ GEOGRAPHY LEARNING OUTCOMES

\section{Correlations}

\begin{tabular}{|c|c|c|c|}
\hline & & AQ & $\begin{array}{l}\text { GROGRAPHY } \\
\text { LEARNING } \\
\text { OUTCOMES }\end{array}$ \\
\hline \multirow{4}{*}{$\mathrm{AQ}$} & $\begin{array}{c}\text { Pearson } \\
\text { Correlation }\end{array}$ & 1 & $0.964^{* *}$ \\
\hline & $\begin{array}{l}\text { Sig. (2- } \\
\text { tailed) }\end{array}$ & & 0.000 \\
\hline & $\mathrm{N}$ & 62 & 62 \\
\hline & $\begin{array}{l}\text { Pearson } \\
\text { Correlation }\end{array}$ & $0.964^{* *}$ & 1 \\
\hline \multirow[t]{2}{*}{$\begin{array}{l}\text { HASIL BELAJAR } \\
\text { GEOGRAFI }\end{array}$} & $\begin{array}{l}\text { Sig. (2- } \\
\text { tailed) }\end{array}$ & 0.000 & \\
\hline & $\mathrm{N}$ & 62 & 62 \\
\hline
\end{tabular}

Source: Processed Data of 2018

Based on the above parson correlation result table shows that the value of $r$ AQ with geography learning result of 0.964 . This figure shows strong correlation between AQ with student geography learning result because $r>0.05$. this is reinforced by two asterisks $(* *)$ with significance of 0.01 which indicates that the higher the high level of AQ students the higher the students' geography learning outcomes.
TABLE VIII. AQ LINEARITY TEST RESULTS WITH GEOGRAPHY LEARNING OUTCOMES

ANOVA Table

\begin{tabular}{|c|c|c|c|c|c|c|c|}
\hline & $\begin{array}{l}\text { Sum of } \\
\text { Square } \\
\text { s }\end{array}$ & df & $\begin{array}{l}\text { Mean } \\
\text { Square }\end{array}$ & $\mathbf{F}$ & $\begin{array}{l}\mathrm{Sig} \\
\cdot\end{array}$ \\
\hline $\begin{array}{l}\text { HASIL } \\
\text { BELAJAR } \\
\text { GEOGRAFI } \\
\text { * AQ }\end{array}$ & $\begin{array}{l}\begin{array}{l}\text { Between } \\
\text { Groups }\end{array} \\
\text { Within G } \\
\text { Total }\end{array}$ & $\begin{array}{l}\text { (Com } \\
\text { bined } \\
\text { ) } \\
\text { Linea } \\
\text { rity } \\
\text { Devia } \\
\text { tion } \\
\text { from } \\
\text { Linea } \\
\text { rity } \\
\text { roups }\end{array}$ & $\begin{array}{l}3.111 \\
\\
0.749 \\
54.932 \\
\end{array}$ & $\begin{array}{l}19 \\
1\end{array}$ & $\begin{array}{l}0.173 \\
0.018\end{array}$ & $\begin{array}{l}160.0 \\
05 \\
2865 . \\
519 \\
\\
9.698\end{array}$ & $\begin{array}{l}0.0 \\
00 \\
0.0 \\
00 \\
\\
0.0 \\
00\end{array}$ \\
\hline
\end{tabular}

Based on the results table calculation of linearity AQ value with the results of learning geography above, produces fhitung of $0.000<\mathrm{ftabel}$ of 2.03. The ftable number is calculated based on the magnitude of the $\mathrm{df}$ value ie, 10.50 with the 0.05 coefficient level. This shows that both variables are linear. Then proceed with correlation calculation.

TABLE IX. THE RESULT OF LINEAR REGRESSION TEST

Model Summary

\begin{tabular}{|c|c|c|c|c|}
\hline Model & $\mathbf{R}$ & R Square & $\begin{array}{l}\text { Adjusted R } \\
\text { Square }\end{array}$ & $\begin{array}{l}\text { Std. Error of the } \\
\text { Estimate }\end{array}$ \\
\hline 1 & $0.964^{\mathrm{a}}$ & 0.930 & 0.929 & 0.254 \\
\hline
\end{tabular}

Based on the linear regression table above explains the value of $r$ value of 0.964 and the value of the correlation determination of 0.930 which means that the influence of $A Q$ on students' geography learning result is $93.0 \%$ while the rest is influenced by other factors.

\section{DISCUSSION}

Based on the research results about correlation between AQ with geography learning results that have been done on the students of class X IPS 1 and X IPS 2 in SMAN 1 Kasihan Yogyakarta showed that there is a positive and significant relationship between the two variables. This is proven by the results of calculation of correlation test with $\mathrm{r}$ value of $0.964 * *>$ 0.05 which means the higher AQ level of a student, then more high student learning geography. In addition, it turns out the level of AQ in a child gives a great influence on learning outcomes, this is evidenced by the magnitude of the percentage of regression value of $93 \%$. This study is in line with the results 
of research conducted by Fajrianti (2012) showed that there is a significant relationship between AQ and achievement motivation on mathematics learning achievement. In his research explained that the level of AQ is very influential on student achievement, because if the student's learning achievement is not accompanied by AQ then will get poor performance, and vice versa if accompanied by AQ then the learning achievement will be better. This research is also in line with the results of research conducted by [8] his hypothesis is proving to have merit assuming the finding show there is a positive and significant relationship between $\mathrm{AQ}$ and the academic well-being.

$\mathrm{AQ}$ is one of the most decisive factors for a person's success. Students with a high AQ level will always be responsible with the things done to finish. They are able to survive and face any difficulties that may affect their learning outcomes.

Based on the calculation of AQ students of class X IPS 1 and IPS 2 in SMAN 1 Kasihan Yogyakarta showed that they tend to be classified as campers. The percentage of students classified as campers is $70.97 \%$ with the average of students' geography learning result is 7.82. Campers are moderate AQ levels. Campers are a group of people who are less interested in trying new things and more often to deliver the opportunity to go forward which is actually an opportunity that can be achieved if implemented with maximum effort. Convenience is a success for campers. When they feel comfortable in an environment and situation, they will feel quite satisfied and do not want to develop themselves. [6] explains that campers can do jobs that demand creativity and take calculated risks, but they usually take a safe path. Campers are not achieving and contributing the most. Although they may have earned a number of awards, campers do not use their full capabilities.

In students who are classified as AQ climbers only have a percentage of $19.35 \%$ of the total number of students class X IPS. The climbers are the ones who are happy about the challenges given to them. They are people who have high confidence to succeed in challenging a challenge. According to Stolzt [6] climbers make the most contributions, they embody almost all of their potential, which continues to grow throughout their lives.

In students who classified as AQ quitters only have percentage as much as $9.68 \%$ with the average score of student learning outcomes of 6.25. Quitters are people who do not like challenges and are more likely to avoid them. The advantages of these quitters are having lots of friends and easy to get along with, but sometimes their ability is hard to accept by other groups, because it doubts its ability. This is because quitters are not responsible for the work that is given, and tend to attack before trying. This is why their learning outcomes tend to be low.

The AQ level contributes greatly in determining student learning outcomes. AQ is used to predict a person's success by measuring and assessing how much of his / her endurance in facing obstacles, so that one can manage and control himself in order to achieve success.

\section{CONCLUSION}

The results showed that there is a positive and significant relationship between AQ students and geography students learning grade X IPS 1 and IPS 2 in SMAN 1 Kasihan Yogyakarta. In addition, AQ students give a strong influence on students 'geography learning outcomes, therefore the higher AQ students will be the better the students' geography learning outcomes.

\section{REFERENCES}

[1] L. W. Anderson and D. R. Krathwohl, Kerangka landasan untuk pembelajaran, pengajaran, dan asesmen [Basic Framework for learning, teaching and assessment]. (Rev. ed). (A. Prihantoro, Transl.). New York: Addison Wesley Longman Inc, 2010.

[2] I. Savickiene, "Conception of learning outcomes in the bloom's taxonomy affective domain,” The Quality of Higher Education, vol. 7, pp. 37-57, 2010. [Online]. Available: http: //eric.ed.gov/?id=EJ900258. [Accessed Apr. 20, 2018].

[3] S. P. Yeh and H. W. Fu, "Effects of cooperative e-learning on learning outcomes,” Eurasia J. of Math., Sci., and Technol. Edu., vol. 10, no. 6, pp. 531-536, 2014. [Online]. Available: http: //www.ejmste.com/ms.aspx?kimlik=10.12973/eurasia.2014.1212a. [Accessed Apr. 20, 2018].

[4] P. G. Stoltz, Adversity quotient: mengubah hambatan menjadi peluang [Adversity quotient: turning obstacles into opportunities], 7th ed. Jakarta: PT Grasindo, 2007.

[5] S. Phoolka and N. Kaur, “Adversity Quotient: paradigma baru untuk mengeksplorasi [Adversity Quotient: new paradigm to explore],” Int. J. of Contemp. Studi Bisnis, vol. 3, no. 4, pp. 67-78, 2012. [5]

[6] P. G. Stoltz, Adversity quotient: mengubah hambatan menjadi peluang [Adversity quotient: turning obstacles into opportunities]. (Hermaya, Transl.). Jakarta: PT Grasindo, 2000.

[7] P. G. Stolzt, Adversity quotient: turning obstacles into opportunities. Canada: John Wiley \& Sons, 1997.

[8] A. Z. Khairani, and S. M. S. Abdullah, "Relationship between adversity quotient and academic well-being among Malaysian undergraduates," Asian J. of Sci. Res., pp. 51-55, 2018. DOI: 10.3923/ajsr. 